\title{
ACCELERATED LEARNING UNTUK ANAK SUPERNORMAL SERTA IMPLEMENTASINYA DALAM PENDIDIKAN DASAR
}

\author{
Oleh: \\ Atikah Syamsi* \\ *Dosen Jurusan PGMI FITK IAIN Syekh Nurjati Cirebon \\ Email:atikah_1384@yahoo.co.id
}

\begin{abstract}
ABSTRAK
Pelayanan pendidikan yang berdiferensiasi dengan menggunakan kurikulum yang berdiversifikasi dapat diimplementasikan melalui penyelenggaraan sistem percepatan kelas (akselerasi). Dengan sistem percepatan kelas, siswa yang memiliki kemampuan dan kecerdasan luar biasa diberi peluang untuk dapat menyelesaikan studi di SD kurang dari 6 tahun (misalnya 5 tahun atau 4 tahun), di SLTP dan SMU masing-masing kurang dari 3 tahun (misalnya 2 tahun), dengan menyelesaikan semua target kurikulum tanpa meloncat kelas. Dari aspek kurikulum, pendidikan untuk anak cerdas istimewa membutuhkan diferensiasi kurikulum yaitu memberikan tugas dan kegiatan belajar yang berbeda dari rata-rata anak seusianya sesuai dengan kebutuhan belajarnya. Diferensiasi kurikulum bagi peserta didik cerdas istimewa dapat dilakukan melalui tiga jalur: enrichment (pengayaan) yaitu kegiatan belajar yang memungkinkan perluasan materi kurikulum, extension (pendalaman) yaitu kegiatan belajar yang memungkinkan investigasi bidang studi secara lebih mendalam, dan acceleration (percepatan) yaitu kegiatan belajar yang memungkinkan untuk menyelesaikan materi belajar dalam waktu yang lebih singkat.
\end{abstract}

Key word : Acceleration, Peserta Didik, Implementasi

\section{A. PENDAHULUAN}

Selama ini, strategi penyelenggaraan pendidikan bersifat klasikal-massal, memberikan perlakuan yang standar (rata-rata) kepada semua siswa, padahal setiap siswa memiliki kebutuhan yang berbeda. Akibatnya, siswa yang memiliki kemampuan dan kecerdasan di bawah rata-rata, karena memiliki kecepatan belajar di bawah kecepatan belajar siswa lainnya, akan selalu tertinggal dalam mengikuti 
kegiatan belajar-mengajar; sebaliknya, siswa yang memiliki kemampuan dan kecerdasan di atas rata-rata, karena memiliki kecepatan belajar diatas kecepatan belajar siswa lainnya, akan merasa jenuh, sehingga sering berprestasi di bawah potensinya (under achiever).

Agar siswa yang memiliki kemampuan dan kecerdasan luar biasa dapat berprestasi sesuai dengan potensinya, diperlukan pelayanan pendidikan yang berdiferensiasi, yaitu pemberian pengalaman pendidikan yang disesuaikan dengan kemampuan dan kecerdasan siswa; dengan menggunakan kurikulum yang berdiversifikasi, yaitu kurikulum standar yang diimprovisasi alokasi waktunya sesuai dengan kecepatan belajar dan motivasi belajar siswa.

Pada hakikatnya, ditinjau dari aspek kemampuan dan kecerdasan, siswa dapat dikelompokkan kedalam tiga strata, yaitu: yang memiliki kemampuan dan kecerdasan di bawah rata-rata, rata-rata, dan di atas rata-rata. Siswa yang berada dibawah ratarata, memiliki kecepatan belajar di bawah kecepatan belajar siswa-siswa pada umumnya. Sedangkan siswa yang berada diatas rata-rata memiliki kecepatan belajar di atas kecepatan belajar siswa-siswa lainnya.

Bagi siswa yang memiliki kemampuan dan kecerdasan rata-rata, selama ini diberikan pelayanan pendidikan dengan mengacu pada kurikulum yang berlaku secara nasional, karena memang kurikulum tersebut disusun terutama diperuntukkan bagi anak anak yang memiliki kemampuan dan kecerdasan rata-rata. Sementara itu, bagi siswa yang memiliki kemampuan dan kecerdasan di bawah rata-rata, karena memiliki kecepatan belajar di bawah siswa-siswa lainnya, diberikan pelayanan pendidikan berupa pengajaran remidi (remedial teaching), sehingga untuk menyelesaikan materi kurikulum membutuhkan waktu yang lebih panjang dari siswasiswa lainnya. Sedangkan bagi siswa yang memiliki kemampuan dan kecerdasan di atas rata-rata, meskipun memiliki kecepatan belajar di atas kecepatan belajar siswasiswa lainnya, belum mendapat pelayanan pendidikan sebagaimana mestinya. Bahkan, kebanyakan sekolah memberikan perlakuan yang standar (rata-rata), bersifat klasikal dan massal, terhadap semua siswa, baik siswa di bawah rata-rata, rata-rata, 
dan di atas rata-rata, yang sebenarnya memiliki kebutuhan berbeda Akibatnya, siswa yang di bawah rata-rata, akan selalu tertinggal dalam mengikuti kegiatan belajarmengajar yang berlangsung; sebaliknya, siswa yang di atas rata-rata, akan merasa jenuh karena harus menyesuaikan diri dengan kecepatan belajar siswa-siswa lainnya.

\section{B. PEMBAHASAN}

\section{Latar Belakang Pembelajaran Akselerasi}

Pemilik konsep ini ialah Dave Meier dengan konsepnya bahwa akselerasi merupakan pembelajaran itu berlangsung secara cepat, menyenangkan, dan memuaskan. Meier menyarankan kepada guru agar dalam mengelola kelas menggunakan pendekatan somatic, auditory, visual dan intelektual (SAVI) ${ }^{1}$. Sementara di Indonesia sebelum lahir UUSPN, terdapat istilah gifted, talented, genius, dan berbakat, yang diinterpretasikan kurang seragam, masing-masing orang memiliki konotasi yang beragam. Namun, ada kecenderungan yang sama bahwa istilah-istilah dimaksud diperuntukkan bagi seseorang yang memiliki kemampuan dan kecerdasan yang melebihi orang-orang pada umumnya yang sebaya dengannya. Berkenaan dengan hal tersebut, pemerintah memberi istilah warga negara yang memiliki kemampuan dan kecerdasan luar biasa \{UUSPN pasal 8 ayat (2)\} untuk menangkap arti dari istilah-istilah gifted, talented, genius maupun berbakat.

Dengan bermacam perbedaan dalam diri peserta didik maka peserta didik adalah pribadi yang unik yang mempunyai kesiapan dan kemampuan fisik, psikis serta intelektual yang beragam. Demikian pula halnya dalam proses belajar, setiap peserta didik mempunyai karakteristik yang berbeda. Sebagaimana firman Allah dalam Al-Qur'an :

\footnotetext{
${ }^{1}$ Bobbi de Porter \& Mike Hernacki, , Quantum Learning: Membiasakan Belajar Nyaman dan Menyenangkan. (Bandung : kaifa, 2000.) hal.14.
} 
Artinya "Perhatikanlah bagaimana kami lebihkan sebagian dari mereka atas sebagian (yang lain). dan pasti kehidupan akhirat lebih Tinggi tingkatnya dan lebih besar keutamaannya." (Q. S. Al-Israa : 21)

Ayat diatas merupakan isyarat yang jelas tentang adanya perbedaan individual antar manusia. Demikian juga dalam belajar, dengan berdasar pada kecakapan dasar umum, maka para ahli sepakat membagi kategori pribadi anak menjadi :

a. Anak superior (supernormal), yaitu anak yang dapat bertindak lebih cepat dan tepat daripada anak sebayanya.

b. Anak rata-rata (normal), yaitu anak yang bertindak biasa-biasa saja dan tidak memiliki kemampuan yang menonjol.

c. Anak dibawah rata-rata (subnormal), yaitu anak-anak yang lambat dalam berpikirnya dikarenakan hal-hal tertentu seperti anak debil.

Anak underachiever, yaitu siswa yang mempunyai taraf intelegensi yang tergolong tinggi, akan tetapi memperoleh prestasi belajar yang tergolong rendah. Secara potensial peserta didik yang mempunyai taraf intelegensi yang tergolong tinggi mempunyai kemungkinan besar untuk memperoleh prestasi belajar yang tinggi pula, akan tetapi dikarenakan hal-hal tertentu semacam minat dan motivasi yang kurang sehingga menyebabkan rendahnya prestasi belajar di kelas.

2. Definisi dan Landasan Hukum Pembelajaran Akselerasi

Dalam kamus Inggris-Indonesia etimologis kata Accelerated berarti "dipercepat" sedangkan Learning seperti istilah-istilah yang sering digunakan oleh banyak Pakar pendidikan mempunyai arti "ilmu pengetahuan"2. Jadi Accelerated Learning ialah proses untuk mendapatkan ilmu pengetahuan dengan cara dipercepat.

Sedangkan secara terminologi Accelerated Learning adalah pelayanan pendidikan bagi anak yang memiliki potensi kecerdasan dan bakat istimewa dalam bentuk program percepatan belajar (akselerasi). Potensi kecerdasan dan bakat istimewa yang dimaksud ialah bakat-bakat dan kemampuan yang ditunjukkan anak

${ }^{2}$ Lihat pada Kamus Lengkap Inggris Indonesia yang disusun oleh S. Wojowasito dan Poerwadarminta, (Jakarta : Hasta, 1983). Kata Accelerated pada hal. 1 dan kata Learning pada hal. 89. 
dalam dunia pendidikan formal maupun diluarnya ${ }^{3}$. Sependapat dengan Sutratinah yang mengutip Munandar dalam laporan Penataran Guru Anak Berbakat mengemukakan bahwa yang menentukan keberbakatan seseorang pada hakikatnya adalah tiga hal yaitu : kemampuan Umum (biasanya diukur dengan tes intelegensi dan prestasi), kreativitas (fleksibilitas dan originalitas dalam berpikir untuk menciptakan sesuatu) dan yang terakhir adalah tanggung jawab terhadap tugas (task commitment).

Konsep akselerasi sendiri sebenarnya adalah cara penanganan anak supernormal dengan cara memperbolehkan naik kelas secara meloncat atau menyelesaikan program regular dalam jangka waktu yang lebih singkat ${ }^{4}$.

Variasi bentuk-bentuk percepatan antara lain :

1) Masuk lebih awal (early admission)

2) Naik kelas sebelum waktunya (advanced placement)

3) Mempercepat pelajaran dan merangkap kelas (advanced course)

Pada tahun 1998-1999, dua sekolah di DKI Jakarta dan satu sekolah swasta di Jawa Barat melakukan ujicoba pelayanan pendidikan bagi anak yang memiliki potensi kecerdasan dan bakat istimewa dalam bentuk program percepatan belajar (akselerasi). Kemudian pada tahun 2000 program akselerasi dicanangkan Mendiknas menjadi program Depdiknas namun baru pada tahun 2001/2002 penetapan diseminasi program percepatan belajar pada beberapa sekolah di beberapa propinsi. Hingga dikeluarkan UUSPN yang mengatur program akselerasi (percepatan), sebagaimana tertuang pada Undang-undang Sistem Pendidikan Bab IV Pasal 5 ayat 4 mengamanatkan bahwa:

"Warga negara yang memiliki potensi kecerdasan dan bakat istimewa berhak memperoleh pendidikan khusus".

${ }^{3}$ Lihat UU Sisdiknas No.2 Tahun 1989, yang dimaksud dengan anak berkemampuan lebih ialah "mereka yang oleh psikolog dan atau guru diidentifikasikan sebagai peserta didik yang telah mencapai prestasi memuaskan dan memiliki kemampuan intelektual umum yang berfungsi pada taraf cerdas dan keterikatan terhadap tugas yang tergolong baik serta kreativitas yang memadai."

${ }^{4}$ Sutratinah Tirtonegoro, Anak Supernormal dan Program Penanganannya, (Jakarta : Bumi Aksara, 2001), hal. 104. 
Sedangkan Bab V Pasal 12 ayat 1 menegaskan bahwa :

"Setiap peserta didik pada setiap satuan pendidikan berhak: mendapat layanan pendidikan sesuai dengan bakat, minat dan kemampuannya menyelesaikan program pendidikan sesuai dengan kecepatan belajar masing-masing dan tidak menyimpang dari batas waktu yang ditetapkan".

Hal ini sejalan dengan amanat Majelis Permusyawaratan Rakyat (MPR), yang

tertuang dalam Garis-garis Besar Haluan Negara tahun 1999,bahwa arah kebijakan pendidikan antara lain adalah melakukan pembaharuan sistem pendidikan termasuk pembaharuan kurikulum, berupa diversifikasi kurikulum untuk melayani keberagaman peserta didik. Selanjutnya, sejalan pula dengan amanat Undang-Undang Nomor 2 Tahun 1989 Tentang Sistem Pendidikan Nasional (UUSPN), yang menegaskan bahwa warga negara yang memiliki kemampuan dan kecerdasan luar biasa berhak memperoleh perhatian khusus pasal 8 ayat (2) dan setiap peserta didik mempunyai hak menyelesaikan program pendidikan lebih awal dari waktu yang ditentukan (pasal 24 butir 6).

Berdasarkan hal tersebut, merupakan kewajiban Pemerintah untuk memfasilitasi sekolah-sekolah dalam penyelenggaraan layanan pendidikan bagi peserta didik yang mempunyai perbedaan dalam kemampuan (kognitif, afektif dan psikomotorik) ${ }^{5}$, serta mengevaluasi penyelenggaraan dan pengelolaannya. Kecerdasan berhubungan dengan kemampuan intelektual sedangkan kemampuan luar biasa tidak hanya terbatas pada kemampuan intelektual ${ }^{6}$. Jenis jenis kemampuan dan kecerdasan luar biasa, yang dimaksud dalam batasan ini meliputi bidang:

(1) intelektual umum dan akademik khusus,

(2) berpikir kreatif produktif,

(3) psikososial/kepemimpinan,

(4) seni/kinestetik,

5 Lihat dalam tulisan M.D. Dahlan " Pendidikan yang Berorientasi pada Perkembangan Siswa" dalam buku Shindunata (ed.), Membuka Masa Depan Anak-anak Kita, (Yogyakarta : Kanisius, 2000), hal. 119.

6 Moegiadi, Perhatian Khusus terhadap Peserta Didik Berbakat. (Jakarta: Badan Pertimbangan Pendidikan Nasional), 1991. hal.7. 
(5)psikomotor.

\section{Kelebihan dan Kekurangan Pembelajaran Akselerasi}

Dalam setiap program tentu tidak terlepas dari kelebihan dan kekurangan, adapun kelemahan pembelajaran akselerasi antara lain:

a). Dalam perdebatan soal pendidikan nasional, banyak dipersoalkan kurangnya pendidikan nilai di sekolah-sekolah, dari SD sampai SMU. Disadari, kebanyakan sekolah terlalu menekankan segi kognitif saja, tetapi kurang menekankan segi nilai kemanusiaan yang lain. Maka mulai disadari pentingnya pendidikan nilai, termasuk pendidikan budi pekerti dan segi-segi kemanusiaan lain, seperti emosionalitas, religiusitas, sosialitas, spiritualitas, kedewasaan pribadi, dan afektivitas. Masalahnya, pendidikan nilai tidak bisa dipercepat, bahkan instan. Pendidikan nilai kemanusiaan memerlukan latihan dan penghayatan yang membutuhkan waktu lama, sehingga sulit dipercepat. Misalnya, penanaman nilai sosialitas perlu diwujudkan dalam banyak tindakan interaksi antarsiswa dan kerja sama; penanaman nilai penghargaan terhadap manusia lain membutuhkan latihan dan mungkin hidup bersama orang lain, dan tidak cukup hanya dengan pengajaran pengetahuannya.

b). Sebagai bangsa, kita perlu membantu anak-anak yang belum dapat menikmati pendidikan. Mereka akan menjadi bagian penting pengembangan bangsa ini di kemudian hari, maka kita bertanggung jawab untuk membantu mereka. Jangan sampai ada segelintir siswa dibantu dipercepat, sedangkan kebanyakan anak yang masih tidak dapat menikmati pendidikan minimal dibiarkan atau tidak diurus karena kurang menarik dan memakan biaya besar.

c). Memaksakan diri dalam berbagai ketimpangan antara banyaknya anakanak yg belum bersekolah dengan anak-anak percepatan tiada ubahnya mengejar 
gengsi, gengsi orang tua mempunyai anak-anak cerdas. Juga gengsi di pihak sekolah, karena akan dianggap sekolah unggulan, dan biaya pendidikan di kelas tersebut relatif memang lebih mahal

d). Pengelompokan siswa secara homogen berdasarkan kemampuan akademik menjadi kelas superbaik, amat baik, baik, sedang, kurang, sampai ke kelas "gombal", tidak memiliki dasar filosofi yang benar ${ }^{7}$. Yang memprihatinkan, pengelompokan itu disertai program promosi dan degradasi. Siswa yang tidak mampu mempertahankan prestasi akademiknya bisa digusur dari kelas superbaik ke kelas sedang. Bahkan mungkin bisa meluncur ke kelas paling bawah, kelas "gombal".

e). Stigmatisasi pada diri siswa yang ada di kelas reguler. Dalam sebuah kesatuan lingkungan, bisa dikatakan bahwa kelas reguler adalah kelas yang relatif jelek bila dibandingkan dengan kelas akselerasi.

f). Timbulnya budaya inferior, muncul kelas eksklusif, arogansi, dan elitisme. Dengan kondisi yang betul-betul berbeda dengan segenap potensi intelektual yang lebih tinggi, jelas siswa-siswa kelas akselerasi akan jauh lebih berprestasi dibanding kelas reguler. Inferioritas pun mudah menghinggapi siswa-siswi kelas reguler, dan sebaliknya eksklusivisme, arogansi dan elitisme akan mudah melekat pada diri siswasiswa kelas akselerasi. Masing-masing siswa membentuk group reference mereka sendiri-sendiri.

g). Terjadi dehumanisasi pada proses belajar di sekolah. Materi pelajaran yang diselesaikan oleh siswa reguler selama satu tahun harus dilalap habis siswa akselerasi selama satu semester (setengah tahun). Dengan alokasi waktu yang jauh lebih pendek ini mau tidak mau siswa harus belajar keras. Segi intelektualitas, potensi mereka memang memungkinkan. Tetapi, mereka bukanlah mesin yang bisa diset untuk hanya melakukan satu aktivitas.

h). Siswa kelas akselerasi tidak memiliki kesempatan luas untuk belajar mengembangkan aspek afektif. Padatnya materi yang harus mereka terima,

\footnotetext{
${ }^{7}$ Andi Hakim Nasoetion. Anak Berbakat dan Kemungkinan Menemukannya di Indonesia. (Jakarta: C.V. Rajawali, 1982), hal. 32.
} 
banyaknya pekerjaan rumah yang harus mereka selesaikan, ditunjang kemampuan intelektual yang mereka miliki dan teman-teman sekelas yang rata rata pandai, membuat iklim kerja sama mereka menjadi terbatas. Tugas-tugas itu bisa mereka selesaikan sendiri.

i). Keberadaan kelas akselerasi ini sebenarnya juga memunculkan pro kontra disana-sini. Sebagian orangtua merasa senang anaknya bisa ikut dalam kelas akselerasi. Sebagian yang lain justru merasa khawatir akan ketidakseimbangan perkembangan psikis anaknya karena menjadi lebih eksklusif di kelas akselerasi. Kelas yang dibuat untuk menampung anak-anak berbakat ini dikhawatirkan mengurangi perkembangan sosialisasi mereka dengan teman-teman lainnya di kelas regular.

j). Di samping itu, terkadang sekolah juga hanya ingin mengejar gengsi sekolah karena mempunyai kelas akselerasi. Siapa yang tidak bangga memiliki murid-murid yang cerdas dan berbakat? Terlebih lagi, suasana diskriminasi akan terasa diantara siswa reguler dan siswa akselerasi. Situasi seperti ini bukan tidak mungkin akan menjadi boomerang tersendiri bagi sekolah dan dunia pendidikan kita.

Sedangkan kelebihan dan keuntungan dari adanya program akselerasi ini antara lain:

a). Kelas ini dirancang menjadi kelas unggulan. Proses rekrutmen untuk melihat potensi siswa dilakukan secara multidimensional. Rekrutmen dilakukan dengan mengembangkan konsep keberbakatan dari Renzulli, Reis dan Smith (1978) ${ }^{8}$. Konsep itu menyebutkan bahwa anak berbakat mempunyai IQ minimal 125 menurut skala Wechsler, selain itu harus mempunyai task commitment dan creativity quotion di atas rata-rata.

b). Dari sisi waktu, penyelenggaraan kelas akselerasi menguntungkan, siswa yang bakat intelektualnya tinggi dibantu secara khusus, sehingga mereka

${ }^{8}$ Renzulli, J.S., S.M. Reis, \& L.H. Smith. The Revolving Door Identification Model. (Connecticut: Creative Learning Press, 1981) 
mendapatkan bantuan pengajaran lebih sesuai bakatnya. Mereka akan dapat cepat lulus, diperkirakan setahun lebih awal dibanding siswa biasa.

c). Keuntungannya lagi terletak pada akselerasi pengajaran. Dengan program percepatan ini diharapkan siswa berbakat tidak bosan di kelas yang sama dengan siswa lain, sehingga tidak mengganggu, mengacau kelas, dan dia dapat terus maju dengan cepat. Kelas model ini memang menjanjikan siswa lebih cepat selesai dibandingkan melalui tahapan-tahapan pada umumnya.

\section{Implementasi pembelajaran Akselerasi terhadap Pendidikan MI}

Pelayanan pendidikan yang berdiferensiasi dengan menggunakan kurikulum yang berdiversifikasi dapat diimplementasikan melalui penyelenggaraan sistem percepatan kelas (akselerasi) ${ }^{9}$. Dengan sistem percepatan kelas, siswa yang memiliki kemampuan dan kecerdasan luar biasa diberi peluang untuk dapat menyelesaikan studi di SD kurang dari 6 tahun (misalnya 5 tahun atau 4 tahun), di SLTP dan SMU masing-masing kurang dari 3 tahun (misalnya 2 tahun), dengan menyelesaikan semua target kurikulum tanpa meloncat kelas. Dari aspek kurikulum, pendidikan untuk anak cerdas istimewa membutuhkan diferensiasi kurikulum yaitu memberikan tugas dan kegiatan belajar yang berbeda dari rata-rata anak seusianya sesuai dengan kebutuhan belajarnya. Diferensiasi kurikulum bagi peserta didik cerdas istimewa dapat dilakukan melalui tiga jalur: enrichment (pengayaan) yaitu kegiatan belajar yang memungkinkan perluasan materi kurikulum, extension (pendalaman) yaitu kegiatan belajar yang memungkinkan investigasi bidang studi secara lebih mendalam, dan acceleration (percepatan) yaitu kegiatan belajar yang memungkinkan untuk menyelesaikan materi belajar dalam waktu yang lebih singkat. Bobbi de porter menganggap akselerasi dapat memungkinakn siswa untuk dapat belajar dengan kecepatan yang mengesankan, dengan upaya yang normal dan dibarengi dengan kegembiraan. Cara ini menyatukan unsur-unsur yang sekilas tampak tidak

${ }^{9}$ E. Mulyasa, Implementasi Kurikulum 2004: Panduan Pembelajaran KBK, (Bandung : Remaja Rosdakarya, 2005), hal. 187. 
mempunyai persamaan, misalnya hiburan, permainan, warna, cara berpikir positif, kebugaran fisik, dan kesehatan emosional. Namun, semua unsur ini bekerja sama untuk menghasilkan pengalaman belajar yang efektif ${ }^{10}$.

Sementara itu peran guru bimbingan dan konseling (BK) juga ditingkatkan dalam upaya mengoptimalkan potensi kecerdasan yang dimiliki peserta didik. Upaya ini dilakukan agar penyelenggaraan progam akselerasi tidak hanya menekankan pada perkembangan intelektual, tetapi harus memperhatikan perkembangan emosional dan sosial anak yang seirama dengan perkembangan keremajaannya ${ }^{11}$. Selain itu program BK diharapkan dapat mencegah dan mengatasi potensi-potensi negatif yang dapat terjadi dalam proses percepatan belajar.

\section{Proses belajar mengajar program akselerasi}

a. Struktur program pengajaran

struktur program pengajaran serta penjelasannya sesuai dengan program pengajaran pada masing-masing kelas tersebut kecuali bagi kelas akselerasi yang mengalami pemadatan materi yang disesuaikan dengan pola berapa yang dipakai. Sedangkan untuk melaksanakan struktur program tersebut maka sekolah menyusun program tahunan, program semester dan rencana persiapan harian sesuai dengan polapola patas diatas.

\section{b. Sistem evaluasi}

Evaluasi yang dilakukan untuk siswa pada program akselerasi pada dasarnya sama dengan yang dilakukan pada program regular, yaitu untuk mengukur ketercapaian materi (daya serap) dalam program akselerasi dengan menggunakan prinsip belajar tuntas sejalan dengan istilah patas itu sendiri yang merupakan singkatan dari Cepat Tuntas.

Adapun sistem evaluasi untuk program patas meliputi :

${ }^{10}$ Sutrisno, Revolusi Pendidikan di Indonesia, Yogyakarta Ar-Ruzz media group, 2005), hal. 34

${ }^{11}$ Baharuddin, dkk, Teori Belajar dan Pembelajaran, (Yogyakarta Ar-Ruzz media group, 2007), hal.134 
1) Ulangan harian, dalam satu semester ulangan harian minimal 6 kali. Bentuk soal yang digunakan adalah bentuk uraian.

2) Ujian Nasional, diikuti oleh siswa akselerasi pada tahun kelima bersamaan dengan pelaksanaan UN siswa regular.

3) Sistem pengisian dan penyerahan raport, siswa akselerasi mempunyai format raport yang sama dengan raport siswa regular, pembagiannya disesuaikan dengan kalender pendidikan program patas yang telah disusun secara khusus.

Tabel 9. Ragam Pola Akselerasi SD/MI'

\begin{tabular}{|c|c|c|}
\hline No & $\begin{array}{l}\text { Macam } \\
\text { pola patas }\end{array}$ & keterangan \\
\hline 1 & pola I-VI & $\begin{array}{l}\text { kelas 1-6 diselesaikan dalam waktu } 5 \text { tahun dengan } \\
\text { pemadatan materi dari kelas 1-6 }\end{array}$ \\
\hline 2 & Pola I-II & $\begin{array}{l}\text { kelas } 1 \text { dan } 2 \text { diselesaikan dalam waktu } 1 \text { tahun melalui } \\
\text { pemadatan materi, selanjutnya kelas 3-6 masing-masing } \\
\text { diselesaikan } 1 \text { tahun }\end{array}$ \\
\hline 3 & pola II-III & $\begin{array}{l}\text { kelas 2-3 dipadatkan } 1 \text { tahun, sedangkan kelas 1,4,5 dan } \\
6 \text { masing-masing diselesaikan } 1 \text { tahun }\end{array}$ \\
\hline 4 & pola III-IV & $\begin{array}{l}\text { kelas 3-4 dipadatkan } 1 \text { tahun, sedangkan untuk kelas } \\
\text { 1,2,5 dan } 6 \text { masing-masing diselesaikan } 1 \text { tahun }\end{array}$ \\
\hline 5 & pola IV-V & $\begin{array}{l}\text { kelas 4-5 dipadatkan } 1 \text { tahun, sedangkan kelas 1,2,3 dan } \\
6 \text { masing-masing diselesaikan } 1 \text { tahun }\end{array}$ \\
\hline 6 & pola V-VI & $\begin{array}{l}\text { kelas 5-6 dipadatkan } 1 \text { tahun, sedangkan kelas 1-4 } \\
\text { masing-masing diselesaikan } 1 \text { tahun }\end{array}$ \\
\hline 7 & pola I-II-III & $\begin{array}{l}\text { kelas 1,2 dan } 3 \text { dipadatkan dalam waktu } 2 \text { tahun, } \\
\text { sedangkan kelas 4-6 masing-masing diselesaikan } 1 \text { tahun }\end{array}$ \\
\hline 8 & $\begin{array}{l}\text { pola II-III- } \\
\text { IV }\end{array}$ & $\begin{array}{l}\text { kelas 2-4 dipadatkan } 2 \text { tahun, sedangkan kelas 1,5 dan } 6 \\
\text { masing-masing diselesaikan } 1 \text { tahun }\end{array}$ \\
\hline 9 & $\begin{array}{l}\text { pola III-IV- } \\
\text { V }\end{array}$ & $\begin{array}{l}\text { kelas 3-5 dipadatkan } 2 \text { tahun, sedangkan kelas 1,2 dan } 6 \\
\text { masing-masing diselesaikan } 1 \text { tahun }\end{array}$ \\
\hline 10 & $\begin{array}{l}\text { pola IV-V- } \\
\text { VI }\end{array}$ & $\begin{array}{l}\text { kelas 4-6 dipadatkan } 2 \text { tahun, sedangkan kelas 1-3 } \\
\text { masing-masing diselesaikan } 1 \text { tahun }\end{array}$ \\
\hline 11 & $\begin{array}{l}\text { pola I-II- } \\
\text { III-IV }\end{array}$ & $\begin{array}{l}\text { kelas 1-4 dipadatkan } 3 \text { tahun, sedangkan kelas } 5 \text { dan } 6 \\
\text { masing-masing diselesaikan } 1 \text { tahun }\end{array}$ \\
\hline
\end{tabular}

${ }^{12}$ Tabel ini berdasar pada ragam pola akselerasi pada SD Muhammadiyah Sapen sebagai sekolah yang mempunyai program akselerasi. 


\begin{tabular}{|c|c|c|}
\hline 12 & $\begin{array}{l}\text { pola II-III- } \\
\text { IV-V }\end{array}$ & $\begin{array}{l}\text { kelas 2-5 dipadatkan } 3 \text { tahun, sedangkan kelas } 1 \text { dan } 6 \\
\text { masing-masing diselesaikan } 1 \text { tahun }\end{array}$ \\
\hline 13 & $\begin{array}{l}\text { pola III-IV- } \\
\text { V-VI }\end{array}$ & $\begin{array}{l}\text { kelas 3-6 dipadatkan } 3 \text { tahun, sedangkan kelas } 1 \text { dan } 2 \\
\text { masing-masing diselesaikan } 1 \text { tahun }\end{array}$ \\
\hline 14 & $\begin{array}{l}\text { pola I-II- } \\
\text { III-IV-V }\end{array}$ & $\begin{array}{l}\text { kelas 1-5 dipadatkan } 4 \text { tahun, sedangkan kelas } 6 \text { tetap } 1 \\
\text { tahun }\end{array}$ \\
\hline 15 & $\begin{array}{l}\text { pola II-III- } \\
\text { IV-V-VI }\end{array}$ & $\begin{array}{l}\text { kelas 2-6 dipadatkan } 4 \text { tahun, sedangkan kelas } 1 \text { tetap } 1 \\
\text { tahun }\end{array}$ \\
\hline
\end{tabular}

Apabila peserta didik yang dihadapi memiliki kunggulan maka pembelajaran harus dirancang dengan keunggulan dalam isi maupun dalam prosesnya. Peserta didik dengan kecerdasan istimewa yang mempunyai kelebihan dalam kecepatan menyelesaikan tugas, mempunyai tingkat keunggulan dalam abtraksi berfikir memerlukan perancangan pembelajaran yang lebih cepat dan lebih unggul dalam tantangan berfikir. Persoalan yang kemudian muncul terkait dengan pelayanan pembelajaran bagi peserta didik cerdas istimewa bagi guru adalah bagaimana mengolah standar Isi (Kepmendiknas 22) untuk dimodifikasi menjadi isi yang sesuai dengan keunggulan peserta didik cerdas istimewa dan meningkatkan tantangan taraf berfikir yang cocok dengan peserta didik yang cerdas tersebut.

Sudah saatnya dalam konteks ini guru meninggalkan cara memilih materi pelajaran dengan bertumpu pada buku paket. Berdasarkan konsep-konsep di atas, seyogyanya mengajar pada kelas peserta didik cerdas istimewa tidak hanya menambahkan dengan penggunaan teknologi informasi dan kominikasi (ICT) tetapi harus pula ditingkatkan bobot materi pelajaran dan bobot kegiatan pembelajaran, sebab tanpa itu sesungguhnya guru telah memberlakukan menu pembelajaran dengan materi yang tidak sesuai dengan karakter mereka yang berkemampuan diatas rerata peserta didik. Disinilah diperlukan guru yang berkedudukan sebagai agen pembelajaran dan profesional. Pembelajaran untuk peserta didik cerdas istimewa memerlukan bentuk pelaksanaan yang multi dimensi agar semua potensi yang istimewa dapat dikembangkan. Di sisi lain, proses pembelajaran yang dilakukan untuk peserta didik bekecerdasan istimewa tetap mengusung nilai-nilai inklusivisitas. 
Artinya peserta didik cerdas istimewa dimungkinkan untuk bergabung dengan peserta didik program reguler untuk mata pelajaran-mata pelajaran tertentu. Hal ini perlu dilakukan agar peserta didik cerdas istimewa tidak merasa sebagai sebuah kelompok eksklusif yang dapat menimbulkan rasa percaya diri yang berlebihan (superiority complex).

\section{KESIMPULAN}

Dalam perdebatan soal pendidikan nasional, banyak dipersoalkan kurangnya pendidikan nilai di sekolah-sekolah, dari SD sampai SMU. Disadari, kebanyakan sekolah terlalu menekankan segi kognitif saja, tetapi kurang menekankan segi nilai kemanusiaan yang lain. Maka mulai disadari pentingnya pendidikan nilai, termasuk pendidikan budi pekerti dan segi-segi kemanusiaan lain, seperti emosionalitas, religiusitas, sosialitas, spiritualitas, kedewasaan pribadi, dan afektivitas. Masalahnya, pendidikan nilai tidak bisa dipercepat, bahkan instan. Pendidikan nilai kemanusiaan memerlukan latihan dan penghayatan yang membutuhkan waktu lama, sehingga sulit dipercepat. Misalnya, penanaman nilai sosialitas perlu diwujudkan dalam banyak tindakan interaksi antarsiswa dan kerja sama; penanaman nilai penghargaan terhadap manusia lain membutuhkan latihan dan mungkin hidup bersama orang lain, dan tidak cukup hanya dengan pengajaran pengetahuannya.

Evaluasi yang dilakukan untuk siswa pada program akselerasi pada dasarnya sama dengan yang dilakukan pada program regular, yaitu untuk mengukur ketercapaian materi (daya serap) dalam program akselerasi dengan menggunakan prinsip belajar tuntas sejalan dengan istilah patas itu sendiri yang merupakan singkatan dari Cepat Tuntas

\section{DAFTAR PUSTAKA}


Baharuddin, dkk. 2007. Teori Belajar dan Pembelajaran, Yogyakarta Ar-Ruzz Media Group.

Bobbi de Porter \& Mike Hernacki. 2000. Quantum Learning: Membiasakan Belajar Nyaman dan Menyenangkan. Bandung : Kaifa.

Dahlan, M.D. 2000. " Pendidikan yang Berorientasi pada Perkembangan Siswa" dalam buku Shindunata (ed.), Membuka Masa Depan Anak-anak Kita, Yogyakarta : Kanisius.

Moegiadi. 1991. Perhatian Khusus terhadap Peserta Didik Berbakat. Jakarta: Badan Pertimbangan Pendidikan Nasional.

Mulyasa, E. 2005. Implementasi Kurikulum 2004: Panduan Pembelajaran KBK, Bandung : Remaja Rosdakarya.

Nasoetion, Andi Hakim. 1982. Anak Berbakat dan Kemungkinan Menemukannya di Indonesia. Jakarta: C.V. Rajawali.

Renzulli, J.S., S.M. Reis, \& L.H. Smith. 1981. The Revolving Door Identification Model. Connecticut: Creative Learning Press.

S. Wojowasito \& Poerwadarminta, Kamus Lengkap Inggris Indonesia. 1983. Jakarta : Hasta.

Sutrisno. 2005.Revolusi Pendidikan di Indonesia,Yogyakarta Ar-Ruzz Media Group.

Tirtonegoro, Sutratinah. 2001. Anak SupernormaL dan Program Penanganannya, Jakarta : Bumi Aksara.

UU Sisdiknas No.2 Tahun 1989. 